\title{
LIABILITY OF DISABILITY INSURER WHERE INSURED HAS RECEIVED TREATMENT UNDER DIRECT SERVICE HEALTH PLAN
}

Where an insured is covered for medical treatment and hospital care under both a medical insurance indemnity policy ${ }^{\mathfrak{l}}$ and a prepaid direct service health plan, ${ }^{2}$ a problem relating to "multiple coverage"3 may arise. Some insurance com-

1 With policies of this type, the insurance company contracts to pay the insured on either an indemnity or a reimbursement basis. With indemnity payment, upon sickness or injury the insured receives a set amount specified in the policy, regardless of the costs of his medical care. With rcimbursement payment, only expenses charged to or incurred by the insured are paid to him, and usually there is a specified maximum. See generally Senate Comm. on Labor and Public Welfare, Health Insurance Plans in the United States, S. REP. No. 359, 82d Cong., 1st Sess. 18-20 (1951) ; Irse, Grour Insurance and EMrployee Retirenent Plans 233 (1953); Hansen, Laws Affecting Group Health Plans, 35 IowA L. Rev. 209, 219-20 (1950); MacLean, The Community Association Approach to Health Insurance in the United States, in WoRID INSURANCE Trends 238 (Gregg \& McGill eds. 1959).

2 Health plans, most of which are nonprofit organizations, provide services to inembers rather than cash benefits. The generic term "health plan" encompasses a number of diverse organizations falling into two broad categories: (1) those operating as an intermediate contracting agency, contracting with the covered individual to provide services or facilities on the one hand, and to pay specified fees to member hospitals or doctors for services rendered by them on the other; and (2) those providing medical benefits directly to the subscriber without an intermediate contracting agency ("direct service plans").

Blue Cross and Blue Shield plans are within the first category. Blue Cross provides hospital care by acting as an intermediary between subscribers and hospitals. The individual subscriber goes to a member hospital with Blue Cross paying the hospital at agreed rates. See generally Garbarino, Health Plans and Collectrve Bargaining 104 (1960); Itse, Grout Insurance and Employee Retirement Plans 230 (1953). Blue Cross plans are subject to regulation by the Cahifornia Insurance Commissioner under a special enabling act, CAL. INs. CODE $\$ \S 11491-516.5$, although CAL. INs. CoDE $\$ 11517$ makes the provisions of the code pertaining to disability pohicies ( $\$ \$ 10270-401)$ inapplicable to nonprofit hospital service plans.

The Blue Shield plan functions similarly to Blue Cross in the area of plyysicians' service and surgical expense, and contracts both for provision of service to the subscriber and payment to physician participants. IrSE, op. cit. supra at 250. A special enabling statute was passed in 1941 for Blue Shield, Cal. Stats. 1941, ch. 629, \$1 (now CaL. CoRp. CoDe \$ 9201). No corporation has ever been formed under this statute, since Blue Shield had incorporated in 1939 as a nonprofit organization under CAI. CORP. CODE $\$ 9200$. Blue Shield is subject to supervision by the attorney general under CAL. CORP. CODE $\$ 9505$ rather than being regulated by the commissioner.

The enabhing statutes for both Blue Cross and Blue Shield plans were passed to avoid the provision of CAI. Bus. \& PROF. CODE $\$ 2008$ forbidding the corporate practice of medicine, and cases enforcing this rule, e.g., People ex rel. State Bd. of Medical Examiners v. Pacific Health Corp., 12 Cal. 2d 156, 82 P.2d 429 (1938), cert. denied, 306 U.S. 633 (1939).

Those plans falling in the second category own facilities and hire doctors in order to provide services directly to the subscriber, without an intermediate contracting agency. Some of these plans, such as the Kaiser Foundation Health Plan, are incorporated under CAL. Corp. CODE $\$ 9200$; others, such as the Los Angeles based Ross-Loos Medical Group, operate as a partnership of physicians to avoid corporate practice of medicine for profit. See generally Governor's Comiar. on Medical Am and Heattr, Heatth Care for Catmfornda 17 (1960); Kaiser Foundation Health Plan, Inc., Restatement of Articles of Incorporation 1 (1956).

3 The term "multiple coverage" is beheved to be more accurate than the phrase "double insurance" when dealing with coverage under a health plan. CAL. INs. CODE $\$ 590$ states that "double insurance" exists where several insurers cover the same person for loss resulting from the same risk. Thus, double insurance in the statutory sense would exist only if health plans 
panies providing coverage for the insured's "actual expenses" have stated they will refuse to pay to the insured the value of services provided by a health plan, where the insured's only out-of-pocket expenses are the dues paid to the plan. ${ }^{5}$

California in 1951 adopted into the Insurance Code the Uniform Individual Accident and Sickness Policy Provisions Law. ${ }^{6}$ Section 10369.5 of the code ${ }^{7}$ contains an optional standard provision allowing an insurer to prorate his liability where there is other valid insurance coverage. ${ }^{8}$ The section provides that for pro-

were considered to be insurers. Although the precise question whether direct service nonprofit health plans are engaged in the insurance business has not been litigated in California, it is almost certain that the question would be answered in the negative. In California Physicians' Serv. v. Garrison, 28 Cal. 2d 790, 172 P.2d 4 (1946), Blue Shield was held not to be engaged in the insurance business and entitled to operate without supervision by the commissioner. While some of the reasons given for the holding in that case are not applicable to a direct service plan, the primary basis of the holding was that the principle object of the plan was "service" rather than "indemnity." This distinction would apply a fortiori to direct service plans of the Kaiser type.

The majority view of legal writers is that health plans are not insurance. See Hansen, Group Health Plans: A Twenty-Year Legal Review, 42 MrNo. L. REv. 527 (1958); Hansen, Laws Affecting Group Health Plans, 35 Iowa L. Rev. 209 (1950); MacLean, The Communtity Association Approach to Health Insurance in the United States, in WorLd INSURANCE TRENDS 238 (Gregg \& McGill eds. 1959); Annot., 167 A.L.R. 322 (1947); 28 GEo. L.J. 273 (1939). Some student writers suggest that group health plans should be recognized as insurance, but of a type not regulated by state insurance laws. Comment, 53 YaLE L.J. 162 (1943); Note, 52 HARv. L. REv. 809 (1939). A third group contends that group plans are insurance. McDavitt, Voluntary Prepayment Medical Care Plans, in Proceedings of the Section of the Insurance LAW of THE ABA 96, 103-06 (1946); Comment, 25 CALIF. L. Rev. 91 (1936); Comment, 1 LA. L. Rev. 809 (1939). See also Comment, 36 Mrcr. L. Rev. 311 (1937) (contingent contracts for services as insurance) ; 3 U. PIrT. L. REv. 250 (1937) (distinction between contracts for services and contracts of insurance). See generally 12 APpLEMAN, INsurance LAW AND PRACTICE \$\$ 7001-02 (1943); Holman \& Cooley, Voluntary Health Instrance in the Uuited States, 35 Iowa L. Rev. 183, 196-204 (1950).

4 These companies generally use in the policy the words "actual expense," "actual cost," "cost incurred," or some similar phrase.

5 See note 35 infra and accompanying text.

6 The Uniform Law provisions are embodied in CaL. Ivs. Code $\$ \S 10320-46,10350-50.12$, 10369.1-.12. Certain standard provisions in sections 10350-50.12 must be included in every policy issued. Sections 10369.2-.12 comprise additional standard provisions optional with the insurer. Any provision respecting subject matter covered by the code must be in the code's specified language. Under section 10369.1, different wording must be approved by the commissioner. Any provision covering subject matter not dealt with by the code must not make the policy as a whole less favorable to the insured, although apparently such provisions need not be approved by the commissioner. CAL. INs. CODE $\$ 10323$.

Although the Uniform Law was intended to apply only to policies issued to individuals as distinct fron group policies, CAL. Irs. CODE $\$ 10270.94$ directs the commissioner to promulgate forms for group disability policies incorporating the provisions of the Uniform Law as adopted in the California Insurance Code. The optional standard provision of CAL. INS. Code $\$ 10369.5$ was made applicable to group insurance issued on or after January 1,1957 , by a departinental ruling of the commissioner, incorporated in CAL. ADMIN. CoDE tit. 10, § 2232.34.

By 1962 only Alaska of the fifty states had not adopted the Uniform Law.

7 CAL. INS. CODE $\$ \$ 10369.5$ and 10369.6 replace $\$ 10364$, the optional standard provision available for policies issued prior to the adoption of the Uniform Law in 1951. Policies issued from 1952 to 1956 could include a provision under $\$ 10364$ or under the Uniform Law code sections. For policies issued after January 1, 1957, the Uniform Law completely replaces $\$ 10364$, although the latter section remains part of the code and applies to policies presently in effect issued prior to 1957 which contain the optional provision of $\S 10364$.

8 This provision states:

Insurance With Other Insurers: If there be other valid coverage, not with this 
rata purposes the value of coverage on a provision of service basis shall be taken as the amount "the services rendered would have cost in the absence of such coverage." If this provision is used, the insurer may further elect to include a definition of "other valid coverage," which must individually be approved as to form by the California Insurance Commissioner ${ }^{9}$ in the absence of such definition, other coverage does not include group insurance, automobile medical payments insurance, or coverage provided by hospital or medical service organizations. ${ }^{10}$ Thus, it would seem that an insurer cannot by proration reduce his liability under a policy subject to the Uniform Law because of health plan coverage unless (1) the above optional standard provision is included in the policy, (2) the definition of "other valid coverage" includes benefits provided by a medical service organization, and (3) the insurer has not been given written notice of the other coverage prior to the occurrence or commencement of loss. ${ }^{11}$ If any of these requirements is not met, the insurer should pay the full amount due under its policy, notwithstanding other coverage under a health plan. If all three requirements are satisfied,

\begin{abstract}
insurer, providing benefits for the same loss on a provision of service basis or on an expense incurred basis and of which this insurer has not been given written notice prior to the occurrence or commencement of loss, the only hability under any expense incurred coverage of this policy shall be for such proportion of the loss as the amount wbich would otherwise have been payable hereunder plus the total of the like amounts under all such other valid coverages for the same loss of which this imsurer had notice bears to the total like amounts under all valid coverages for such loss, and for the return of such portion of the premiums paid as shall exceed the prorata portion for the amount so determined. For the purpose of applying this provision when other coverage is on a provision of service basis, the "like amount" of such other coverage shall be taken as the amount which tlie services rendered would have cost in the absence of such coverage.
\end{abstract}

It is to be noted that this provision refers to otber coverage on a provision of service basis under the heading of "Insurance With Other Insurers," which raises the question whether direct service health plans are to be considered as insurance. See note 3 supra. The termimology, however, is at least consistent with the view that direct service plans are insurance, but not of a type regulated by insurance statutes.

${ }^{\circ}$ CAL. INS. CODE $\$ 10369.5$.

10 Ibid.

11 The purpose of the notice provision is to allow the insurer to reduce any possible overinsurance by cancelling its policy, either at the expiration of the period for which it has accepted a premium, or immediately upon a return of the unearned premium to the insured. If the policy is allowed to remain in effect after notice of other insurance, there can be no reduction in hability. Dustin v. Interstate Business Men's Acc. Ass'n, 37 S.D. 635, 159 N.W. 395 (1916) ; Satterfield v. Inter-Ocean Cas. Co., 159 Tenn. 531, 19 S.W.2d 229 (1929); Rietz, Standard Provisions-Personal Contracts, in Accident and Stckness Insurance 99, 109-10 (McCahan ed. 1954).

The practice of including noncancellation or guaranteed renewable clauses in disability policies is growing. Conroy, Guaranteed Renezvable-Noncancellable $A$ and $H$ Insurance: What's in a Name, 405 INs. L.J. 650 (1956) ; Grahame, Noncancellable and Guaranteed Renewable $A$ and $H$ Instirance, 404 INs. L.J. 567 (1956). Where an insurer cannot cancel its policy because of such a clause, there is apparently no way for the insurer to avoid full liability and the notice requirement thereby becomes ineffective to control overinsurance. But after a lapse of a noncancellable policy, which might arise from tardy payment of premiums, the insurer will apparently be allowed to refuse reinstatement on the ground tbat the insured has other policies and appears overinsured. Kahn v. Continental Cas. Co., 325 Ill. App. 1, 59 N.E.2d 524 (1945). 
the indemnity insurer may prorate reimbursement, ${ }^{12}$ but must return to the insured the amount of premiums which exceed payment of the prorata share. ${ }^{13}$

In Stites v. California-Western States Life Ins. Co. ${ }^{14}$ plaintiff, who was issued a policy of medical expense insurance by defendant in 1954, subsequently became a member of the Kaiser Foundation Health Plan. He was later treated for an illness at a Kaiser Foundation hospital. As a dues paying member of the health plan, he received at no additional expense services valued at $\$ 1,571.72$, of which $\$ 693.00$ would ordmarily have been covered by defendant's policy. Defendant's policy was to indemnify the insured against "the actual expense" and "for actual

12 The prorata provision of $\S 10369.5$ is similar to that of the 1912 Standard Provisions Law, which the Uniform Law was intended to replace. Compare CAL. INS. CoDE $\$ \$ 10369.5, .6$ and Accident AND Sickness Insurance app. B at 279-80 (McCahan ed. 1954), with Cat. INS. Code $\$ 10364$ and Accident AND Sickness Insurance, supra app. A at 268.

Cases applying the prorata provision under the older law include Woods v. Nat'l Life \& Acc. Ins. Co., 166 So. 501 (La. Ct. App. 1936); Wall v. Commonwealth Cas. Co., 225 Mo. App. 657, 39 S.W.2d 441 (1931); Dustin v. Interstate Business Men's Acc. Ass'n, 37 S.D. 635, 159 N.W. 395 (1916). For a discussion of the prorata provision of the $1912 \mathrm{law}$, see generally Wetterlund, Claim Problems in the Health and Accident Field, in Proceedings of the Section OF INSURANCE LAW OF THE ABA 32 (1949).

13 The provision for the return of excess premiums apparently has not been applied in a reported case. The question as to the amount of premiums to be returned was specifically left open in Woods v. Nat' Life \& Acc. Ins. Co., 166 So. 501 (La. Ct. App. 1936), although the court indicated that return of a prorata portion of the premiums for the time that "other insurance" had been carried would be proper.

The provision is difficult to apply. Suppose, for example, that $Y$ carried policy $A$ providing for $\$ 1,000$ maximum medical expense coverage at a premium rate of $\$ 1.00$ per month, and later acquires policy $B$ providing a maximum of $\$ 5,000$ medical expense coverage at a premium rate of $\$ 5.00$ per month. If two years after the second pohicy acquisition $Y$ is injured and his expenses total $\$ 3,000$, under the prorata formula policy $A$ would pay $1 / 0 \times \$ 3,000$, or $\$ 500$, while pohicy $B$ would pay $\% \times \$ 3,000$, or $\$ 2,500$. It is not clear what amount the insurer $A$ is required to return as excess premiums, and at least two possibilities are presented: (1) $\%$ of the two year premium payments, or $\$ 20$, since insurer $A$ was required to pay only $1 \%$ of the total; or (2) $1 / 2$ of the two year premium, or $\$ 12$, since $\$ 500$ represents half of the face amount of policy $A$. The second choice would seem preferable, since the $1 / 6$ ratio would be constant no matter what the amount of $Y$ 's expense. For example, if $Y$ had $\$ 5,000$ of expenses, $A$ would be liable for $1 / 6 \times \$ 5,000$, or $\$ 833.33$, and $A$ in that event should be allowed to retain a larger share of the premiums paid. If the second formula were applied to the latter example, $A$ would be required to return $17 \%$ of the premiums paid for the previous two years. The amount of return under this formula represents the percentage that the policy liability is reduced because of other insurance, the computation of which must always await the determination of the insured's expenses.

A further argument can be made that logically no premiums should be refunded merely because one incident occurs in which the expenses do not fully utilize the insured's combined coverage. That is, for the period during which premiums were being paid, the insured was fully covered up to $\$ 6,000$. If he is not injured at all he still is getting the protection he is paying for. If he is injured and incurs expenses to a lesser extent than his maximum coverage, he was still covered for the contingency of larger expenses. In short, the insured should not be reimbursed his premium payments if he was at all times provided the coverage for which he paid.

If it is decided that some return of premiums is required, another related question arises: Should the insurer be required to pay interest on the excess premiums returned? In addition, could an insured, upon acquisition of a second insurance policy, demand successfully that he pay a reduced or prorated premium for the earher coverage? If not, would he be entitled to a premium refund upon cancellation or expiration of the policy, where he had never made a clain for policy benefits?

14 A.D. No. 147, App. Dep’t Super. Ct., San Mateo County, Oct. 5, 1961. 
cost charged such insured"15 for medical care. Defendant refused to pay the insured's claim for the value of services rendered by Kaiser, ${ }^{16}$ but recovery was allowed in the municipal court. ${ }^{17}$ Defendant appealed, contending that the insured had incurred no out-of-pocket expense and therefore had suffered no loss. ${ }^{18}$ In what was apparently a case of first impression in California, ${ }^{10}$ the appellate department of the superior court reversed, agreeing with defendant that the insured had suffered no loss under the terms of the policy. ${ }^{20}$ Neither the court nor counsel cited provisions of the Insurance Code.

The Stites case seems to fall squarely within the provisions of the Uniform Law. Since defendant's policy did not contain the "other coverage" prorata pro-

15 Ibid.

16 Kaiser provided plaintiff with an informational statement specifying the value of the services given. Opening Brief for Appellant, p. 3, Stites v. Cahifornia-Western States Life Ins. Co., A.D. No. 147, App. Dep't Super. Ct., San Mateo County, Oct. 5, 1961.

17 Stites v. Califorma-Western States Life Ins. Co., A.D. No. 147, App. Dep't Super. Ct., San Mateo County, Oct. 5, 1961. The municipal court decision is unreported.

18 Opening Brief for Appellant, pp. 1-3, 5, Stites v. California-Western States Life Ins. Co., supra note 17. Appellant clained that the insured had received free medical treatment for which recovery should be denied, relying on United States v. St. Paul Mercury Indem. Co., 238 F.2d 594 (8th Cir. 1956) ; Protective Indus. Ins. Co. v. Gray, 40 Ala. App. 578, 118 So. 2d 289 (1960) ; Drearr v. Connecticut Gen. Life Ins. Co., 119 So. 2d 149 (La.1960). Opening Brief for Appellant, pp. 3-4. In the St. Paul case, a veteran was accepted at a Veterans' Hospital under a statute entitling him to free care and treatment upon execution of an affidavit of inability to pay. An insurer of the veteran was sued by the Veterans' Administration, which had taken an assignment of the veteran's rights under a polio policy providing payment for expenses actually incurred in required medical care. The court demed recovery on the grounds that under the statute the veteran had incurred no liability to the Government arising from hospitalization. The Drearr case reached the same result on essentially the same facts as the St.Paul case. In Gray, where the insured was provided with free hospital treatment by the state and by charity, the court held the insured could not assert a claim against the insurer for items of "actual hospital expense." Appellant argued that these cases could not be distinguished from the one at issue even though plaintiff bad paid a premium for the health plan coverage, since the insured in the cited cases had given valid consideration for the free treatment received in the form of military services rendered.

Plaintiff, on the other hand, rehed heavily on Kopp v. Home Mut. Ins. Co., 6 Wis. 2d 53, 94 N.W.2d 224 (1959), where plaintiff was insured by both a Blue Cross plan and an indemnity policy. In the latter the insurer promised "to pay all reasonable expenses incurred ... to or for the named imsured ...." After hospitalization paid for by Blue Cross, plaintiff sought payment from the insurance company. He recovered, the court stating that Blue Cross had incurred expense for hospital service to the plaintiff, that the policy did not specify who was required to incur the expense im order that the insured recover, and that this raised an ambiguity to be resolved against the insurer.

Plaintiff in Stites argued that although no paynnent was made for treatment at the time it was rendered, Stites had paid such expense in the form of dues as a prepaying member of the health plan; that even if the latter were not determinative of the issue, the Kopp case established that out-of-pocket expense was not a prerequisite to recovery; that health plans were not listed as specific exclusions in the pohicy, thereby raising an ambiguity to be resolved against the insurer. Brief for Respondent, pp. 2-6. In answer to plaintiff's first point, defendant claimed that the dues prepaid to the health plan were in the nature of a premium, and that to allow recovery on the basis that this constituted expense in effect anounted to a subsidization of plaintiff's premium payments to Kaiser. Closing Brief for Appellant, p. 2.

19 No reported case arising under the Uniform Law and involving a health plan has been discovered im any United States jurisdiction.

${ }^{20}$ Stites v. California-Western States Life Ins. Co., A.D. No. 147, App. Dep't Super. Ct., San Mateo County, Oct. 5, 1961. 
vision permitted by the Insurance Code, ${ }^{21}$ it should have been required to pay without regard to coverage. Although the latter conclusion is not explicit in the code, no other result would give meaning to the existence of section 10369.5.22

Had the plaintiff relied on the Insurance Code, the defendant could possibly have argued that proration is inapplicable unless there is first established an underlying liability to be prorated. The fact that no out-of-pocket expenses were paid or owed by the insured would seem to support this argument, and this was the crux of the case as it was decided by the court without consideration of the Insurance Code. However, the wording of section 10369.5, which allows proration when other coverage is on a provision of service basis, seems to negate a narrow definition of insurer's liability such as that found by the Stites court. Health plans are the only organizations providing services directly to members, ${ }^{23}$ and would seem to be the only possible reason for the Uniform Law's reference to other coverage on a provision of service basis. Health plans normally do not charge prepaying members for the value of the services rendered. ${ }^{24}$ Furthermore, section 10369.5 explicitly states: "[W] basis . . . such other coverage shall be taken as the amount which the services rendered would have cost in the absence of such coverage." (Emphasis added.) Thus it appears that the Uniform Law not only provides when there may be prorating of liability, but also fixes the liability of indemnity insurers even though the other coverage is under a health plan and involves no out-of-pocket expense.

In addition to the foregoing analysis based on the Uniform Law, there is further support for rejecting the Stites decision. Insurers previously have sought approval by the commissioner of policy provisions specifically conditioning their liability on either actual payment of or an obligation to pay the claimed loss by the insured. If such provisions are used, the insurer incurs no liability when the insured was rendered services under a health plan. On two occasions, however, insurance companies have been unsuccessful in attempting to gain approval of such restrictive clauses. Refusal each time was based on an opinion of the California attorney general interpreting the Insurance Code, at the request of the

21 Brief for Respondent, p. 5, Stites v. California-Western States Life Ins. Co., A.D. No. 147, App. Dep't Super. Ct., San Mateo County, Oct. 5, 1961, states: "The insuring clause of the policy in question here reads as follows: 'This policy insures against loss hereinafter specified if such loss is not covered by Workmen's Compensation or by the provisions of any State or Federal act which provide benefits to workmen . . . if such loss results from sickness.'"

22 If the insurer could avoid liability completely by not using the prorata provision, no use would exist for the provision. More logical is the conclusion that prorata liability is the least that the insurance company can incur, and to do this it must comply with the statutory requirements.

Since the policy in Stites was issued during the transition period between 1952 and 1956, the defendant had a cloice of whether or not to comply with the Uniform Law. See note 7 supra. Nevertheless, the same reasoming should apply under the code prior to the Uniform Law, and unless the provision of $\$ 10364$ was used there should be no reduction of liability in any event. See Dustin v. Interstate Business Men's Acc. Ass'n, 37 S.D. 635, 159 N.W. 395 (1916) (dictum); text following note 28 infra.

23 Insurance companies do not provide services directly to beneficiaries, for to do so would violate the rule against the corporate practice of medicine embodied in CaL. Bus. \& Pror. CODE $§ 2008$.

24 Some plans unay cliarge the member nommal fixed sums for office or lome visits. Health plans sometimes charge niembers a fractional or reduced amount in the event of childbirtl, or for hospitalization. See University of California, Group Health and Life Insurance Program Prospectus, Jan. 1, 1962. 
commissioner. In the first opinion, ${ }^{25}$ the question considered was whether a disability policy providing payment of medical expenses on a reimbursement basis could require actual payment of the expenses by the insured as a condition precedent to recovery. The attorney general concluded that section 10176 of the Insurance Code did not permit this "actual payment" clause. ${ }^{26}$ This position was reaffirmed in 1959 by an opinion forbidding a policy provision excluding "expenses for which neither the employee nor the dependant is required to make payment."27 Thus, Stites reached a result that the commissioner expressly has declined to authorize. If a clause that provides for no liability where the insured has not first paid or been obligated to pay his medical costs is disallowed, surely the forbidden result is not permissible in the absence of the clause.

Since the policy in Stites was issued in 1954, the insurer could have used section $10364^{28}$ of the old Insurance Code rather than section 10369.5 of the Uniform Law, with regard to prorating liability ${ }^{29}$ To consider fully the implication of the failure to use any prorata provision in the Stites policy, ${ }^{30}$ the content of

257 OPS. CAI. ATt'y Gen. 227 (1946).

26 The insurance company sought to include the following clause in its policy: "No benefit shall be payable with respect to a hospital confinement in a hospital owned or operated by the United States Government except in reimbursement of cliarges actually made and paid by the employee." The attorney general's opinion discusses early authority holding that accident and health imsurance was not a contract of indemnity or reimbursement to be measured by values lost to the insured, but an "investment contract" providing for payment of a set amount upon the occurrence of the disability, without regard to actual monetary loss. The opinion noted that there is some question whether California origmally followed this principle, but that the "investment contract" theory was adopted by the enactment of CAL. INs. CODE § 10111 in 1935. As originally enacted, $\$ 10111$ read: "In life or disability insurance, unless the interest of an insured is susceptible of exact pecuniary measurement, the measure of indemnity is the sum fixed in the policy." Cal. Stats. 1935, ch.145, §10111, at 637. In the same year, § 10111 was amended to its present form: "In life or disability insurance, the only measure of liability and damage is the sum or sums payable in the manner and at the times as provided in the policy to the person entitled thereto."

The enactment of $\$ 10111$ raised doubts whether the modern type of disability contract indemnifying against the actual cost of medical, surgical or hospital services rendered could lawfully be issued. Earlier forms of hospital benefit clauses provided for percentage increases in the weekly indemnity for the time the insured was actually hospitalized, regardless of the actual cost of hospitalization, rather than reimbursing the insured for the amount of the hospital bill.

It was against this background that CAL. INs. CoDE $\$ 10176$ was enacted in 1943: "In disability insurance the policy may provide for payment of medical, surgical or lospital expenses upon a reimbursement basis, and provision may be made therein for payment of all or a portion of the amount of the charge for such services without requiring that the insured first pay such expenses." The attorney general reasoned that the first clause of $\$ 10176$ was an exception to $\S 10111$ and that the second clause defined the scope of the exception; thus the term "reimbursement basis" employed in $\S 10176$ was interpreted as permitting reimbursement for liability for medical and hospital bills instead of reimbursement for payment thereof. The conclusion of the opinion, therefore, indicates that the investment contract theory of disability insurance is still valid in California, by which a right of payment arises upon the occurrence of the disability, without regard to actual monetary loss. The expenses incurred or cost of services could be the measure of payment, but would not determine liability. The latter would seem to be established upon the occurrence of the disability and the commencement of treatment.

2734 Ops. Cax. ATr'y GeN. 247, 248 (1959). This ruling laid to rest any distinction between "actual payment," dealt with in the first opinion, and an "obligation to pay" as conditions precedent to the insurer's liability.

28 CAL. INs. CODE $\$ 10364$, quoted in note 31 infra.

29 See note 7 supra.

${ }^{30}$ See note 21 supra and accompanying text. 
section 10364 must be analyzed. ${ }^{31}$ This section refers only to "other insurance covering the same loss," and, unlike section 10369.5, does not specifically refer to coverage on a provision of service basis. It seems clear, however, that once the insurer's liability is established, inclusion of section 10364 in a policy is the only way of reducing that liability as a result of other insurance..$^{32}$ But, because section 10364 does not mention provision of service coverage, it would not seem to establish the insurer's liability in the absence of out-of-pocket expense on the part of the insured ${ }^{33}$ Nevertheless, the insurer's liability under the old code still would be predicated on section 10176 as interpreted by the attorney general. Therefore, combining sections 10364 and 10176 leads to the conclusion that Stites was incorrect regardless of whether the insurer argued applicability of the Uniform Law or the old code provisions.

The Stites decision has significance beyond that of the average unreported case, and notwithstanding the oversight of plaintiff's counsel in failing to cite the Insurance Code and the opinions of the attorney general. In 1961, when the case was decided, the appellate department of the superior court was the court of last resort for cases originating in municipal or justice courts in California. ${ }^{34}$ As the pronouncement of the highest court with jurisdiction of the subject matter to have considered the problem, a number of insurance companies have seized upon the Stites case as a justification for denying claims. ${ }^{35}$ Thus, in a very real and practical sense, the case has made an impact on the insurance community, affecting the payment of claims and limiting the rights of the insured.

Double recovery of the type rejected by Stites, but which seems to be required under the Insurance Code, is not a subject lacking public concern ${ }^{38}$ With today's high cost of medical care, ${ }^{37}$ coverage under two or more policies often may provide less than complete protection to an insured. Overinsurance ${ }^{38}$ exists only where

31 Section 10364 provides:

If the insured shall carry with another company, corporation, association or society other insurance covering the same loss without giving written notice to the insurer, then in that case the insurer shall be liable only for such portion of the indemnity promised as the said indemnity bears to the total amount of like indemnity in all policies covering such loss, and for the return of such part of the premium paid as shall exceed the prorata for the indemnity thus determined.

32 See note 22 supra. If health plan coverage was not considered "other insurance" within the meaning of $\S 10364$, then the insurer would not be able to prorate his hability despite the other coverage under the health plan.

33 See text following note 22 supra, with regard to hability being established by $\$ 10369.5$.

34 See CaI. Const. art. VI, $\S 4,4 \mathrm{~b}, 5$; Golden v. Stansbury, Inc., 155 Cal. App. 2d 480, 318 P.2d 134 (1957) ; McMurtry v. Lucero, 122 Cal. App. 2d 636, 265 P.2d 164 (1954); Unemployinent Reserves Comm'n v. St. Francis Homes Ass'n, 58 Cal. App. 2d 271, 137 P.2d 64 (1943).

35 Twelve of twenty insurance comparies polled stated that claims by members of direct service health plan members would be denied on the basis of the Stites decision. Telephone Interviews With Insurance Conipany Representatives Conducted by Kaiser Foundation Health Plan Legal Department, Aug. \& Sept. 1962.

30 See Governor's Comm. on Medical Aid and Heatth, Health Care for Calmfornia 23 (1960) ; 1 Nat's Ass's INs. Comm'rs Proceedings 90 (1962); 1 id. at 331 (1961); 2 id. at 549 (1960) ; 117 Daily Labor Report, June 15, 1962, p. B-1 ; Friedman, Perils in Personnel Insurance, Dun's Review, Feb. 1962, p. 79; LeClair, Overinsurance Dangers, 443 Ins. L.J. 775 (1959); Robbins, The Measurement of Voluntary Health Insurance Coverage in the United States, 49 Axr. J. Pub. Hearte 875, 879 (1959).

37 Governor's Comoc. on Medicat Am and Heattr, Heatth Care for Calmornin 22-24 (1960) ; 2 Nat'l Ass'n Ins. Coman'rs Proceedings 549, 551-52 (1960).

38 The term "overinsurance" is often used interchangably with the terms "double insur- 
the total benefits under all coverage exceeds any reasonable expectation of financial or service needs. ${ }^{39}$ From the standpoint of public policy, it lias been argued that overinsurance "furnishes the insured individual with a 'profit' incentive which is contrary to the public interest in that it distorts the function of the insurance mechanism." "40 The opposing viewpoint is that the insured individual paying for the policies should be permitted to receive the benefits paid for under each of them.11

The prospect of overinsurance did not prevent recovery in three California cases where such result was not required by the disability provisions of the Insurance Code. ${ }^{42}$ In each of these cases the plaintiff was covered both by a direct service health plan and by an automobile liability policy with supplementary disability provisions. Recovery under the liability policy was awarded in each case, ${ }^{43}$ despite expense free services being provided under the health plan, and even though the disability provisions of the Insurance Code are specifically excluded

ance," "additional insurance," and "other insurance," although the terns are not always identical. 1 Nat'u Ass's Ins. Comma'Rs Proceedings 331, 333 (1961); 2 id. at 549-50 (1960); see note 39 infra.

39 Double insurance need not be overinsurance. The scope of each policy, the amount of benefits provided, and current medical care costs are key considerations in determining whether an individual is overinsured. It would be inaccurate to say that there is overinsurance where an insured suffers a $\$ 1,000$ injury because he bas several policies providing a total of $\$ 3,000$ in benefits, since risk must also be taken into account. It is not too improbable that a $\$ 4,000$ injury could have occurred, in which circumstance the individual would be underinsured. Therefore, a determination whether an individual is overinsured should be made as of the time the various policies were acquired, and not on the basis of a given injury. In Stites, for example, plaintiff possibly had greater coverage than he needed with reference to the particular injury of that case; however, he was not necessarily overinsured.

Double coverage may be retained voluntarily by an individual because of the added protection it is thought to afford. In addition, one of the coverages may have been acquired involuntarily through an employer-employee "group health plan," or both coverages may have been acquired involuntarily, since employed married couples will frequently be independently covered by group health plans which include dependent coverage of the spouse. 2 NaT'L Ass'N Ins. Conma'rs Proceedings 549, 551 (1960).

402 NAt's Ass's Ins. Compr'rs Procerdings 549, 550 (1960). See also Dustin v. Interstate Business Men's Acc. Ass'n, 37 S.D. 635, 159 N.W. 395 (1916) ; Friedman, Perils in Personnel Insurance, Dun's Review, Feb. 1962, pp.779-80; LeClair, Overinsurance Dangers, 443 Ins. L.J. 775 (1959).

11 See the dissenting comment of Zetterberg in Governor's Comm. on MEdical Am and Heatrt, Health Care for Caltrornta 23 (1960). In Batchelor v. Ainerican Health Ins. Co., 234 S.C. 103, 107 S.E.2d 36 (1959), the insured was allowed to collect from an insurer although he was covered by nine other hospital and surgical expense policies. The insured earned $\$ 65$ weekly, the total payment benefits under all pohcies being $\$ 745$ per week. The court held the contract was not a gaunbling contract and not void as against public policy, the rule being "that a person baving an insurable interest may insure such interest in whatever amount and in as inany companies as be desires." Id. at 112, 107 S.E.2d at 41 . The court quoted the Uniform Law provision in its code allowing proration, pointing out that defendant should have inserted that provision if it wished to bmit liability to a prorata share. A student note indicates that the result of the case is consistent with the probable viewpoint of other jurisdictions. Note, 11 MERCER L. Rev. 233 (1959).

42 Feit v. St. Paul Fire \& Marme Ins. Co., 209 A.C.A. 321 (App. Dep't Super. Ct. 1962); Bertolino v. Republic Indem. Co. of America, Civil No. A9250, App. Dep't Super. Ct., Los Angeles County, June 26, 1957; Hill v. Firemen's Ins. Co. (San Francisco Munic. Ct., July 6, 1959), Los Angeles Daily Journal, Nov. 30, 1959, p. 29.

43 The theory supporting recovery varied in each of the cases. In Bertolino v. Republic Indem. Co. of America, Civil No. A9250, App. Dep't Super. Ct., Los Angeles County, June 26, 1957, plaintiff sued as assignee of the hospital and doctors of the health plan who bad treated 
from application to automobile disability policies. ${ }^{44}$ The fact situations in these three cases were substantially the same as in Stites, except that automobile policies were involved. Thus under the present status of California law, health plan treatment does not preclude additional recovery under an automobile liability policy, though such result is not required by the code, while substantially the same type recovery may be denied in cases specifically within the bounds of the code.

It is important that the effect of the Stites case be vitiated and that the provisions of the Uniform Law be given their intended and clear scope of application. Otherwise, insurance companies can settle those relatively few claims exceeding $\$ 5,000$, thereby avoiding the original jurisdiction of the superior courts, while relying on Stites in refusing to pay the smaller claims which would be tried in municipal or justice courts. ${ }^{45}$ The latter type of controversies probably would involve small risk of litigation to the insurance companies, and since cases actually tried are likely to be unreported the resolution of the Stites problem would become further retarded. ${ }^{46}$

her. The court treated the action as one for contribution, allowing recovery for half the face amount of defendant's policy. The court apparently assumed that the obhigation to provide indemnification in money was the same as the obligation to provide services directly. Only if the same performance were promised by each would the obligation be presumed to be joint rather than several under Cax. Crv. Code \& 1431. Contribution under Cax. CTV. CoDE \& 1432, allowed only where the obligation is joint, or joint and several, could then be had. See generally RestateMent, Resittution \$ 81, comment $b$ (1937); 4 Corbin, Contracts $\$ 925$, at $702-03$ (1951).

In Hill v. Firemen's Ins. Co. (San Francisco Mumic. Ct., July 6, 1959), Los Angeles Daily Journal, Nov. 30,1959, p.31, the court held that lack of a provision specifically excluding liability where there was health plan coverage rendered the policy ambiguous; that the health plan had for consideration incurred a liability to furnish and pay for plaintiff's medical services; and that defendant would only be doing wbat it bad contracted to do when required to pay plaintiff's expenses up to the policy limit.

In Feit v. St. Paul Fire \& Marine Ins. Co., 209 A.C.A. 321, 324-25 (App. Dep't Super. Ct. 1962), the court held that the policy in its entirety was not ambiguous, and hy lack of appropriate exclusionary language showed an intention on the part of the insurer to pay for medical expenses incurred regardless of whether the insured was legally ohligated to pay them.

$44 \mathrm{CAC}$. INs. CODE $\& 108$ exempts disability coverage written as part of automobile liability policies from all Insurance Code sections relating to disability policies. Thus $\$ \S 10111$ and 10176, and the opinions of the attorney general interpreting those sections, would be inapplicable to automobile liability policy disability provisions. See note 26 supra and accompanying text. Apparently, automobile pohicies could either make actual payment of the medical costs by the insured a condition precedent to liability, or entirely exclude benefits where there is health plan coverage by use of an unambiguous exclusionary clause.

It is beyond the scope of this comment to pursue the question why automobile liahility policy disability provisions are exempted in California from Insurance Code regulation of disability policies in general. The result of this exemption is that regulation of disabihity insurance can vary depending only on the nature of the contract to which the disability provisions are appended.

45 Car. Code Crv. Proc. $\$ \S 89$ and 112 set out the jurisdictional amounts for cases tried in municipal and justice courts.

46 If a case involved a sum exceeding $\$ 5,000$ and therefore was tried in the superior court, the district court of appeal and supreme court would exercise normal appellate jurisdiction. An appellate decision on this level, which would be reported, could clearly resolve tbe issue. The insurance companies may prefer to have the question unresolved, lowever, for without an available precedent the bargaining power of the insurer is enhanced. Since cases decided in the appellate departments of the superior courts are frequently unreported, as was true of the Stites and Bertolino cases, plaintiff's counsel may have difficulty in finding Cahifornia cases in poimt. Similarly, the $H$ ill case, altlough reported in a legal newspaper, would not appear readily accessible in the usual channels of research. Neither Beriolino nor $H$ ill were cited by 
The status of California law relating to disability insurance can be clarified in several ways. A new appeal procedure, made effective in 1962 subsequent to the Stites decision, enables cases originating in municipal or justice courts to be heard in a district court of appeal, where necessary to secure uniformity of decision or to settle important questions of law. ${ }^{47}$ Should the situation in Stites arise again it is to be hoped that such procedure would be employed. In addition, the commissioner could seek an opinion from the attorney general ${ }^{48}$ establishing the applicability of the Uniform Law, and thereby persuade the insurance companies to ignore Stites as a basis for refusing payment of claims. A suit for declaratory relief might be instituted by either the insured, the insurer, or the health plan. ${ }^{49}$ Another alternative would be for the direct service health plans to include a provision in membership contracts limiting their obligations in the event the member was also insured by an indemnity insurance company. ${ }^{30}$ This would be an undesirable result, opening up litigious controversy of the kind which has flowed from prorata, excess, and escape clauses in the property and liability insurance fields. ${ }^{51}$ Lastly, legislation might be sought to eliminate overlapping coverage ${ }^{62}$

plaintiff in Stites. Insurance companies, on the other hand, are usually well aware of all cases decided that affect their interests. For example, of twenty insurance conipanies interviewed, see note 35 supra, all were aware of the Stites decision, although it was unreported. With a certified report of that case from the court clerk in hand, the companies could use it as a lever to discourage suits by the insured. Secondly, they could call the court's attention to the Stites case, or other favorahle decisions, in future appellate department hitigation. Although Stites would not be controlling, it might well be persuasive to the court.

47 This procedure is contained in CAL. Code Crv. Proc. $\$ 988$, effective as of January 1 , 1962. The section was added under a 1960 amendment by the voters to the state constitution. See Car. Const. art. VI, §4e; 36 CAL. S.B.J. 718 (1961). See generally Bishop, Is It to BeThe Late Appellate Department?, 33 CaL. S.B.J. 152 (1958); Selvin, Proposition 13, 35 CaL. S.B.J. 332 (1960). Since CaL. Const. art. VI, § 4c, gives the California Supreme Court authority to transfer any case pending in a district court of appeal to itself, CaI. Code CIv. Proc. $\S 988$ t opens the way for review by the supreme court of any appropriate case originating in a justice or municipal court.

48 CAL. INS. CODE $§ 12923$.

${ }^{40}$ CAL. Code CIv. Proc. $\S 1060$. But available administrative remedies must have first been exhausted. See Imperial Mut. Life Ins. Co. v. Caminetti, 59 Cal. App. 2d 501, 139 P.2d 691 (1943).

50 Seemingly this could not be achieved by use of the subrogation doctrine, simce subrogation apparently has no place in a disability insurance contract. 34 Ors. CAL. ATT'y GEN. 247 (1959). Subrogation does not follow an actual primary liability, but is allowed only in favor of one who under a legal or moral compulsion pays the debt of another; it is never allowed in favor of a person who is himself personally hable for the debt he discharges by payment. Michigan Hosp. Serv. v. Sharpe, 339 Mich. 357, 63 N.W.2d 638 (1954). In other words, subrogation is an incident of suretyship and is not allowed where two principals are independently liable for the performance of covenants.

51 For a cursory introduction to the complexity and scope of the problem, and the volume of litigation, in the property and liability fields, see generally Russ, The Double Insurance Problem-A Proposal, 13 Hastings L.J. 183 (1961) ; Comment, 5 Stan. L. Rev. 147 (1952); Note, 28 INd. L.J. 429 (1953) ; 26 So. CAL. L. Rev. 331 (1953) ; 5 U.C.L.A.L. Rev. 157 (1958),

62 Merely prohibiting "double coverage" or other insurance by statute would not be an adequate solution. It is not clear whether "other insurance" should be proscribed with reference to the insured, who is in the best position to know that he has duplicate coverage, or with reference to the insurer. The latter is interested in selling as inuch insurance as possible for profit. If an insurer is allowed to profit unjustly by retention of premiums paid where the insured has received benefits under other coverage, little incentive will be provided for insurance companies to limit selling duphicative policies. The ignorance of the general public that additional coverage is forbidden or of no use to thein may make the enforcement of a ban on overinsurance better directed at the insurance companies themselves. 
as well as the involuntary payment of premiums for duplicate coverage under group insurance contracts. ${ }^{53}$

An insured in California with both indemnity insurance and health plan membership presently may be paying premiums for worthless or unnecessary coverage. While double coverage or overinsurance is an area of both legislative ${ }^{64}$ and public interest, ${ }^{55}$ it should be of no judicial concern in disability cases subject to the Uniform Law. The clear guidelines of the Uniform Law should be assiduously applied to make clear the relationship between the health plans, the insurance companies, and the insured.

Carl R. Pagter

53 Overlapping or double coverage may exist involuntarily, as discussed in note 39 supra. Duplication of coverage in individual as distinguished from group policies inust also be considered. Figures on individuals covered both by some form of medical or hospital insurance and a liealth plan are not available. Scattered statistics are available on duplication of insurance generally. Results of surveys indicate from 11.7 to $22 \%$ of the total number insured have multiple coverage. See 2 NAT'L Ass's INs. Comar'rs ProceEdings 549, 551-61 (1960); Robbins, The Measurement of Vohtntary Health Insurance Coverage in the United States, 49 AM. J. Pub. Hearth 875, 879 (1959).

54 The currency of these considerations is shown by the proposals for amendment to the provisions of the Uniform Law. An unenacted bill introduced in the 1961 California Legislature would have amended CAL. INS. CODE $\$ 591$ and added new $\$ \$ 10350.13$ and 11512.05 , providing for prorata liability in all cases where a person was covered by two or more hospital service plan contracts and disability insurance policies. A.B. 568, Cal. Leg., Reg. (Gen.) Sess. (1961). The bill did not cover direct service medical plans outside the regulatory scope of the Insurance Code, nor did it provide for a return of excess premiums upon proration.

The Health Insurance Association of America, an organization of indemnity insurers, submitted a draft of an amendment to the "other insurance" provisions of the Uniform Law. The amendinent greatly broadens the definition of other valid coverage, provides that if the other coverage does not contain an "other insurance" clause, the policy of the indemnity insurer with such a clause would be "excess" coverage, and generally includes provisions more favorable to the insurer. Although double insurance or overinsurance is not prohibited, the insured would be limited in benefits collectible to no more than the cost of allowable medical expense. No provision is made for return of premiums, and the provisions apply whether or not the insurer lras been given written notice of other coverage. 1 NAT'L Ass'N INS. Comin'Rs ProCEEDINgs 90, 93-95 (1962). The National Association of Insurance Commissioners has had two subcounmittees studying the problem for the last three years. The study is continuing. Ibid.

See generally Governor's Comm. on Medical Aid and Health, Health Care for CaliFORNIA 22-23 (1960).

55 See note 36 supra. 